\title{
Hippea maritima gen. nov., sp. nov., a new genus of thermophilic, sulfur-reducing bacterium from submarine hot vents
}

\author{
M. L. Miroshnichenko, ${ }^{1}$ F. A. Rainey, ${ }^{2}+$ M. Rhode ${ }^{3}$ \\ and E. A. Bonch-Osmolovskaya ${ }^{1}$
}

Author for correspondence: M. L. Miroshnichenko. Tel: +7 095 1350131. Fax: +7 0951356530. e-mail:mir@inmi.host.ru

\footnotetext{
1 Institute of Microbiology, Russian Academy of Sciences, Prospect 60 Letiya Oktyabrya 7/2, 117811 Moscow, Russia

2 DSMZ German Collection of Microorganisms and Cell Cultures,

Braunschweig, Germany

${ }^{3} \mathrm{GBF}$, German National Biotechnology Center, Braunschweig, Germany
}

\begin{abstract}
Three strains of moderately thermophilic, sulfur-reducing bacteria were isolated from shallow-water hot vents of the Bay of Plenty (New Zealand) and Matupi Harbour (Papua New Guinea). Cells of all isolates were short, Gramnegative, motile rods with one polar flagellum. All strains were obligate anaerobes and grew optimally at pH 5.8-6.2, 52-54 ${ }^{\circ} \mathrm{C}$ and $2 \cdot 5-3 \%(\mathrm{w} / \mathrm{v}) \mathrm{NaCl}$. Growth substrates were molecular hydrogen, acetate and saturated fatty acids; one of the strains, isolated from Matupi Harbour, was able to utilize ethanol. Elemental sulfur was required for growth. $\mathrm{H}_{2} \mathrm{~S}$ and $\mathrm{CO}_{2}$ were the only growth products. No growth occurred in the absence of $100 \mathrm{mg}$ yeast extract $\mathbf{1}^{-1}$. The $\mathrm{G}+\mathrm{C}$ content of the DNA determined for the type strain $\mathrm{MH}_{2}{ }^{\top}$ was $40.4 \mathrm{~mol} \%$. Results of $16 \mathrm{~S}$ rDNA sequencing indicated that these strains represent a distinct lineage most closely related to the genus Desulfurella. On the basis of the results of morphological, physiological and phylogenetic studies, a new genus, Hippea gen. nov., is proposed with the type species Hippea maritima gen. nov., sp. nov., of which the type strain is $\mathrm{MH}_{2}^{\top}$ (= DSM 10411 ).
\end{abstract}

Keywords: Hippea maritima gen. nov., sp. nov., thermophilic bacteria, sulfur reduction, submarine hot vents

\section{INTRODUCTION}

Anaerobic, thermophilic, sulfur-reducing bacteria were found to inhabit diverse volcanic environments where organic matter and elemental sulfur are available. These include cyanobacterial mats, communities of sulfur-accumulating thermophilic bacteria, bottom deposits of volcanic lakes and submarine hot vents (Bonch-Osmolovskaya, 1994; Miroshnichenko et al., 1994, 1998b). All organisms described to date belong to the genus Desulfurella, which contains four species, Desulfurella acetivorans (Bonch-Osmolovskaya et al., 1990), Desulfurella multipotens (Miroshnichenko et al., 1994), Desulfurella kamchatkensis (Miroshnichenko et al., 1998a) and Desulfurella propionica (Miroshnichenko et al., 1998a). All these organisms are Gramnegative short rods, able to oxidize a wide spectrum of

\footnotetext{
tPresent address: Department of Biological Sciences, Louisiana State University, Baton Rouge, LA 70803, USA.

The EMBL accession number for the 16S rDNA sequence of strain $\mathrm{MH}_{2}{ }^{\top}$ is Y18292.
}

non-fermentable substrates, including molecular hydrogen, volatile and long-chain fatty acids and some organic acids. They are moderate thermophiles and neutrophiles, growing at temperatures of $40-75^{\circ} \mathrm{C}$ and at $\mathrm{pH} 6 \cdot 0-7 \cdot 5$. All representatives of Desulfurella inhabit terrestrial hot springs and do not require $\mathrm{NaCl}$ for growth. In this publication we present a description of a new group of thermophilic, sulfur-reducing bacteria inhabiting marine thermal environments.

\section{METHODS}

Sampling and enrichment. All samples used in this work were obtained during the eighteenth cruise of the Russian scientific vessel ' $A$. Nesmeyanov' in the regions of shallow-water hot vents of the south-western Pacific Ocean. Samples from two different sites were used for the enrichment and isolation of marine, thermophilic, sulfur-reducing bacteria. These samples were from submarine hot vents of the Bay of Plenty, New Zealand, located at $40 \mathrm{~m}$ depth and obtained by scubadivers, and the tidal zone of Matupi Harbour, Papua New Guinea. Temperatures in the sampling points were $56^{\circ} \mathrm{C}$ (Bay of Plenty) and $55^{\circ} \mathrm{C}$ (Matupi Harbour) and the $\mathrm{pH}$ was 6.0 and 6.5 , respectively. Samples from the Bay of Plenty 
were taken in glass tubes $20 \times 250 \mathrm{~mm}$ and stopped with rubber stoppers. In this work, the upper part of the sand column, enriched with elemental sulfur, was used. Samples from Matupi Harbour were collected in glass vials during low tide and the vials were closed with butyl stoppers and screw caps. Samples were used for inoculation immediately on board the vessel. For enrichment of thermophilic, sulfurreducing bacteria the following medium was used (in $\mathrm{g} \mathrm{l}^{-1}$ unless indicated): $\mathrm{NH}_{4} \mathrm{Cl}, 0.33 ; \mathrm{KCl}, 0.33 ; \mathrm{KH}_{2} \mathrm{PO}_{4}, 0.33$; $\mathrm{CaCl}_{2} .2 \mathrm{H}_{2} \mathrm{O}, 0 \cdot 33 ; \mathrm{MgCl}_{2} \cdot 6 \mathrm{H}_{2} \mathrm{O}, 0 \cdot 33 ; \mathrm{NaCl}, 25 \cdot 0$; sodium acetate, 5.0 (or ethanol, $0.5 \%$ ); yeast extract, 0.1 ; $\mathrm{Na}_{2} \mathrm{~S} .9 \mathrm{H}_{2} \mathrm{O}, 0.5 ; \mathrm{NaHCO}_{3}, 0.5$; resazurin, 0.002; trace elements (Balch et al., 1979), $1 \mathrm{ml} \mathrm{l}^{-1}$; vitamins (Wolin et al., 1963), $1 \mathrm{ml} \mathrm{l}^{-1}$. Elemental sulfur was added as an aqueous suspension of sulfur flowers to a final concentration of $10 \mathrm{~g}$ $1^{-1}$. The $\mathrm{pH}$ was adjusted to 6.5 with $2.5 \mathrm{M} \mathrm{H}_{2} \mathrm{SO}_{4}$. After dispensing into $15 \mathrm{ml}$ Hungate tubes with screw caps, the headspace $(5 \mathrm{ml})$ was filled with an $\mathrm{N}_{2} / \mathrm{CO}_{2}$ gas mixture $(4: 1, \mathrm{v} / \mathrm{v})$. Inoculated tubes were incubated at $55^{\circ} \mathrm{C}$. Growth was followed by light microscopy of the culture broth and by measurement of hydrogen sulfide.

Isolation of pure cultures. Pure cultures of sulfur-reducing bacteria were obtained from liquid enrichments by serial dilution in medium of the same composition, solidified with $1.5 \%(\mathrm{w} / \mathrm{v})$ agar (Difco), and consequent isolation of single colonies. In this case, elemental sulfur was replaced by polysulfide (Widdel \& Pfennig, 1992).

Analytical methods. The cell density was determined by direct cell counting in a light microscope. Gaseous and liquid fermentation products were detected by means of GLC (Miroshnichenko et al., 1994). Hydrogen sulfide was measured by a colorimetric method (Trüper \& Schlegel, 1964).

Morphology and ultrastructure studies. Morphology of new isolates was studied with a light microscope. The ultrastructure of whole cells was studied with a JEM-100 electron microscope (JEOL), preparations being stained with phosphotungstate as described previously (Bonch-Osmolovskaya et al., 1990). For ultrathin sectioning, cells were fixed in $3 \%$ glutaraldehyde $/ 5 \%$ formaldehyde in PBS for $1 \mathrm{~h}$ on ice. After washing with the same buffer, samples were dehydrated with a graded series of acetone on ice. In-block staining was performed overnight with $2 \%$ uranyl acetate in $70 \%$ acetone. Samples were embedded in Spurr's resin. After polymerization of the resin at $70^{\circ} \mathrm{C}$ for $8 \mathrm{~h}$, samples were trimmed and cut with glass knives (Ultracut $\mathrm{S}$; Leica). Sections were collected onto 300-mesh copper grids and post-stained with uranyl acetate and lead citrate. Samples were examined in a Zeiss EM 910 transmission electron microscope at an acceleration voltage of $80 \mathrm{kV}$ and at calibrated magnifications.

Physiology of growth. Organic growth substrates were added at $0.5 \%$ concentration, organic acids as their sodium salts. When molecular hydrogen served as substrate, the headspace $(10 \mathrm{ml})$ was filled with an $\mathrm{H}_{2} / \mathrm{CO}_{2}$ gas mixture $(4: 1$, $\mathrm{v} / \mathrm{v})$. Possible electron acceptors were added at $0.2 \%$ concentration.

$\mathbf{G}+\mathbf{C}$ content of the DNA. Determination of the $\mathrm{G}+\mathrm{C}$ content was carried out as described previously (Miroshnichenko et al., 1994).

16S rDNA sequence determination. Genomic DNA extraction, PCR-mediated amplification of the 16S rDNA and purification of PCR products were carried out as described previously (Rainey et al., 1996). Purified PCR products were sequenced by using the Taq DyeDeoxy terminator cycle sequencing kit (Applied Biosystems) as directed in the manufacturer's protocol. Sequencing reaction products were electrophoresed by using the Applied Biosystems 373A DNA Sequencer.

Phylogenetic analysis. The ae2 editor (Maidak et al., 1994) was used to align the $16 \mathrm{~S}$ rDNA sequence of strain $\mathrm{MH}_{2}{ }^{\mathrm{T}}$ against the 16S rDNA sequences of representatives of the various subclasses of the Proteobacteria available from public databases. The final alignment of the sequence was against the previously published 16S rDNA sequences of Desulfurella species (Rainey et al., 1993; Miroshnichenko et al., 1998a). Pairwise evolutionary distances were computed using the correction of Jukes \& Cantor (1969). The leastsquares distance method of De Soete (1983) was used for construction of the phylogenetic dendrogram from distance matrices.

Nucleotide sequence accession numbers. The accession numbers of the reference strains used in the phylogenetic analyses are as follows: Agrobacterium tumefaciens (D14506); Alcaligenes faecalis (M22467); Campylobacter jejuni (L14630); Desulfobacterium autotrophicum (M94409); Desulfobulbus propionicus (M34410); Desulfomonile tiedjei (M26635); Desulfovibrio desulfuricans (M34113); Desulfovibrio halophilus (U48243); Desulfovibrio vulgaris (M34399); Desulfurella acetivorans (72768); Desulfurella kamchatkensis (Y16941); Desulfurella multipotens (Y16943); Desulfurella propionica (Y16942); Escherichia coli (X80725); Rhodocyclus purpureus (M34132); Syntrophobacter wolinii (X70905); and Wolinella succinogenes (M88159).

\section{RESULTS}

\section{Enrichment and isolation of pure cultures of marine, thermophilic, sulfur-reducing bacteria}

After inoculation with samples from submarine hot vents, growth of motile short rods was observed with acetate or ethanol as the energy substrate after 3-5 d incubation at $55^{\circ} \mathrm{C}$, accompanied by the formation of significant quantities of hydrogen sulfide (up to $30-$ $40 \mathrm{mM}$ ). When serial dilutions were transferred to agar medium in roll-tubes, round, flat, white-greyish colonies appeared, up to $0.5 \mathrm{~mm}$ in diameter. After the isolation of colonies in liquid medium, three pure cultures were obtained. The isolate from Matupi Harbour growing on ethanol was designated $\mathrm{MH}_{3}$, the strain from the same sample growing on acetate was $\mathrm{MH}_{2}{ }^{\mathbf{T}}$ and the only isolate from the Bay of Plenty that grew on acetate was designated $\mathbf{B P}_{1}$.

\section{Morphology and ultrastructure}

Cells of all isolates were short rods, $1-3 \times 0.4-0.8 \mu \mathrm{m}$, single or in pairs, motile with one long polar flagellum (Fig. 1a). Gaps (empty spaces) could often be observed in the cytoplasm (Fig. 1b). Thin sections revealed the Gram-negative structure of the cell wall (Fig. 1c). The cytoplasm was of an uneven density. Formation of spores was never observed.

\section{Physiology of growth}

All isolates grew in the temperature range $40-65^{\circ} \mathrm{C}$ and grew optimally at $52-54^{\circ} \mathrm{C}$. Growth was observed in the $\mathrm{pH}$ range $5 \cdot 7-6 \cdot 5$ with an optimum at 5.8-6.2. 

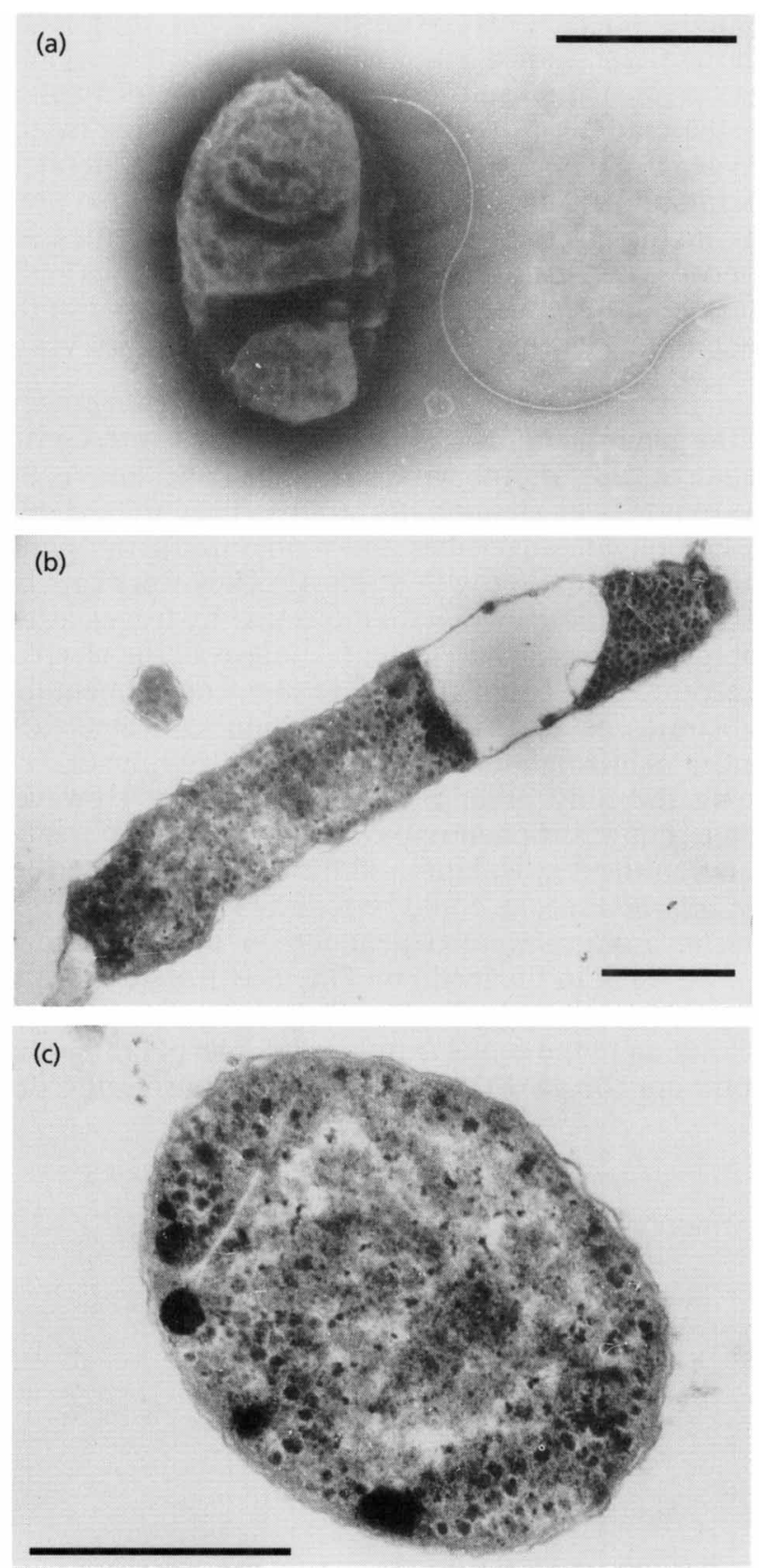

Fig. 1. Negatively stained whole cells (a) and thin-sectioned cells $(b, c)$ of strain $\mathrm{MH}_{2}^{\top}$. Bars, $0.5 \mu \mathrm{m}$.

$\mathrm{NaCl}$ was required in the concentration range $2 \cdot 0$ $3.0 \%(\mathrm{w} / \mathrm{v})$. No growth was observed without prereduction of the medium, which completely excluded oxygen. Addition of $0.02 \%(\mathrm{w} / \mathrm{v})$ yeast extract was found to be required.

\section{Growth substrates and products}

In the presence of elemental sulfur, isolate $\mathrm{MH}_{3}$ was able to grow on, in addition to ethanol, molecular hydrogen, acetate, pyruvate and saturated fatty acids

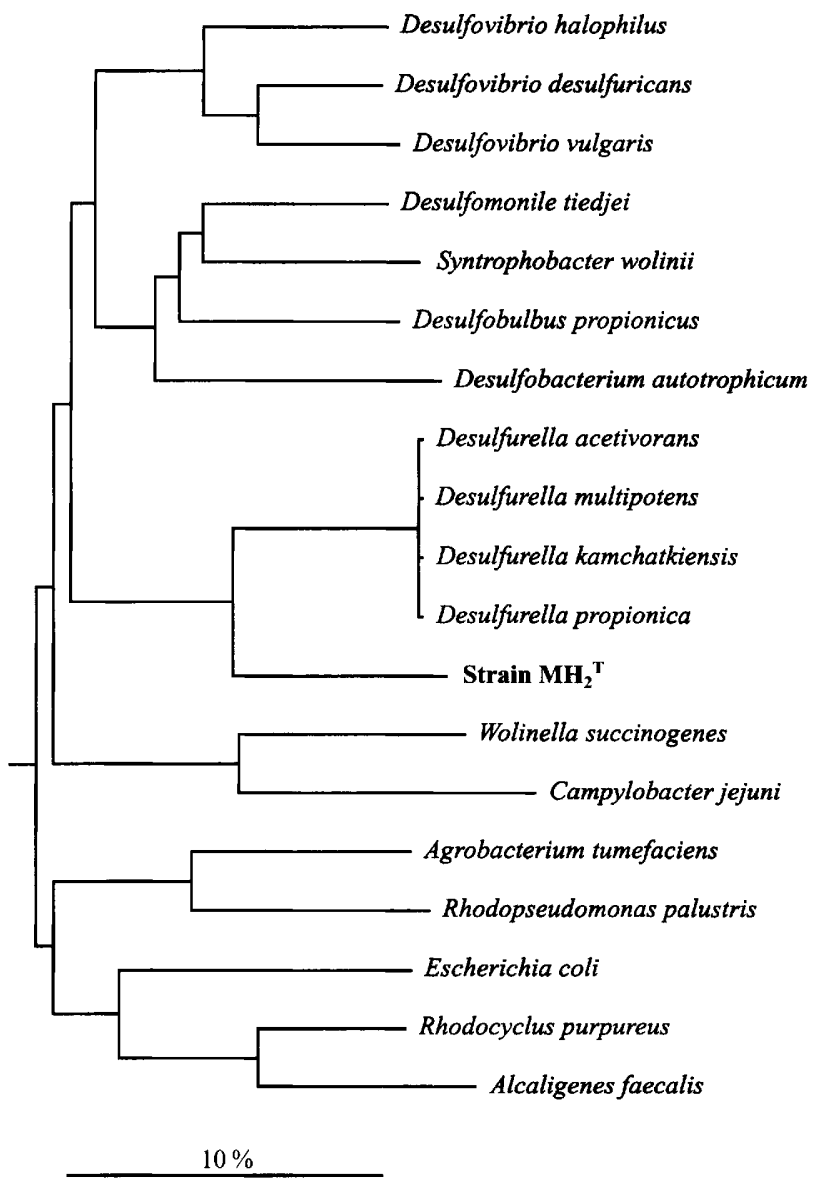

Fig. 2. Phylogenetic dendrogram based on $165 \mathrm{rDNA}$ sequence comparisons indicating the position of strain $\mathrm{MH}_{2}{ }^{\top}$ within the radiation of the Proteobacteria. The scale bar indicates 10 inferred nucleotide substitutions per 100 nucleotides.

(stearate and palmitate). Isolates $\mathrm{MH}_{2}{ }^{\mathrm{T}}$ and $\mathrm{BP}_{1}$ grew on the same substrates with the exception of ethanol. Weak growth of all the isolates was observed with fumarate as the substrate and elemental sulfur as the electron acceptor. None of isolates grew on formate, propionate, butyrate, pyruvate, lactate, succinate, glucose, starch, peptone, methanol or hexadecane. On all the substrates, $\mathrm{CO}_{2}$ and $\mathrm{H}_{2} \mathrm{~S}$ were the only products detected.

\section{Electron acceptors}

Elemental sulfur was required for growth by all three isolates studied. No growth occurred in the absence of sulfur on any of the substrates tested, neither could it be substituted for by any of following electron acceptors: thiosulfate, sulfite, sulfate, fumarate, cystine, nitrate or ferric iron.

\section{$\mathbf{G}+\mathbf{C}$ content of DNA}

The $\mathrm{G}+\mathrm{C}$ content of the DNA of strain $\mathrm{MH}_{2}{ }^{\mathrm{T}}$ was found to be $40 \cdot 4 \mathrm{~mol} \%$. 


\section{S rDNA sequence analysis}

Almost complete 16S rDNA sequences were determined for the three strains. The three sequences were identical. The $16 \mathrm{~S}$ rDNA sequence of strain $\mathrm{MH}_{2}{ }^{\mathrm{T}}$ comprised 1614 nucleotides between $E$. coli positions 32 and 1530. Comparison of this sequence with representatives of the Proteobacteria showed it to have highest similarity to the previously determined sequences of the four species of the genus Desulfurella. The identities were in the range $87.5-88.1 \%$. The identities between the sequence of strain $\mathrm{MH}_{2}{ }^{\mathrm{T}}$ and the sequences of other representatives of the Proteobacteria included in Fig. 2 were in the range 77.3$82.7 \%$. The phylogenetic dendrogram shown in Fig. 2 shows strain $\mathrm{MH}_{2}^{\mathrm{T}}$ to represent a distinct lineage within the Proteobacteria that clusters with the members of the genus Desulfurella as its closest relative. The bootstrap value for the clustering of strain $\mathrm{MH}_{2}{ }^{\mathrm{T}}$ with the Desulfurella species cluster was $100 \%$ on the basis of 1000 data samplings.

\section{DISCUSSION}

Elemental sulfur is the most common form of sulfur in volcanic environments, both terrestrial and submarine. Thermophilic, sulfur-reducing bacteria belonging to the genus Desulfurella inhabit different terrestrial thermal environments, rich in organic substrates and elemental sulfur, making sulfur reduction an important part of the anaerobic carbon cycle (Bonch-
Osmolovskaya, 1994; Miroshnichenko et al., 1998b). The habitats studied here were also very rich in organic matter; elemental sulfur was constantly supplemented by the oxidation of volcanic hydrogen sulfide by the oxygen in cold ocean water. We found that moderately thermophilic, sulfur-reducing bacteria were also present in these habitats. Their catabolic capacities are almost as broad as those of Desulfurella and thus made marine sulfur reducers an important component of the anaerobic microbial food web in submarine hot vents.

In many features, the new isolates resembled members of the genus Desulfurella. Their cells were short, Gramnegative rods, motile with one polar flagellum, as are the majority of Desulfurella strains. They were shown to be obligate anaerobes and moderate thermophiles showing optimal growth at $55^{\circ} \mathrm{C}$. They were capable of lithotrophic growth with molecular hydrogen as the energy substrate and elemental sulfur as the electron acceptor. They could also utilize such non-fermentable substrates as acetate and long-chain saturated fatty acids, oxidizing them completely to $\mathrm{CO}_{2}$ with $\mathrm{H}_{2} \mathrm{~S}$ being the only other product of growth. However, some significant phenotypic and genotypic differences between the new isolates and the previously described Desulfurella species could be found (Table 1). The new marine isolates were dependent on the presence of $2-3 \% \mathrm{NaCl}$ in the medium. One new isolate was able to grow on ethanol, a feature never found in any strain belonging to the genus Desulfurella. The $\mathrm{pH}$ range and optimum for growth were lower for marine thermo-

Table 1. Comparative characteristics of terrestrial and marine thermophilic sulfurreducing bacteria

The terrestrial, thermophilic, sulfur-reducing bacteria of the genus Desulfurella (Terrestrial) are compared with the new marine isolates (Marine). (+), Weak growth.

\begin{tabular}{|lcc|}
\hline Feature & Terrestrial & Marine \\
\hline Morphology & $\begin{array}{c}\text { Short rods, motile } \\
\text { or non-motile }\end{array}$ & Short, motile rods \\
Optimal growth temperature $\left({ }^{\circ} \mathrm{C}\right)$ & $55-60$ & $52-54$ \\
Optimal growth pH & $6 \cdot 8-7 \cdot 0$ & $5 \cdot 8-6 \cdot 0$ \\
Requirement for $\mathrm{NaCl}$ & - & + \\
Requirement for yeast extract & - & + \\
Growth substrates: & + & + \\
$\mathrm{H}_{2}$ & + & + \\
Acetate & $+^{*}$ & - \\
Propionate & $+^{*}$ & + \\
Butyrate & $+^{*}$ & + \\
Saturated fatty acids & - & - \\
Ethanol & $+^{*}$ & - \\
Pyruvate & $+^{*}$ & + \\
Lactate & $+^{*}$ & + \\
Succinate & $+^{*}$ & - \\
Fumarate & $-^{*}$ & \\
Requirement for elemental sulfur & & \\
\hline
\end{tabular}

* Not true for all species/strains. 
philic sulfur reducers than for terrestrial ones. They also differed in their ability to grow autotrophically on mineral medium: marine strains, in contrast to the terrestrial strains, required the presence of yeast extract.

There was also a large difference between the $\mathrm{G}+\mathrm{C}$ content of the DNA of the new isolates and the previously described Desulfurella species. The $\mathrm{G}+\mathrm{C}$ content of the marine isolates differed by $8-9 \mathrm{~mol} \%$ from that of the Desulfurella species ( 40 vs $31-$ $32 \mathrm{~mol} \%$, respectively).

The genus Desulfurella has been shown to represent a distinct branch within the class Proteobacteria (Rainey et al., 1993). Comparison of $16 \mathrm{~S}$ rDNA sequences of the newly isolated strains with those of the Desulfurella species and representatives of the Proteobacteria shows that all three isolates with identical sequences belong to the same species and represent an individual lineage branching with the Desulfurella lineage. Together with Desulfurella, the new isolates represent a distinct lineage within the Proteobacteria closest to the $\delta$ subclass. Additional gene sequences will be required to determine whether this lineage represents a new subclass of the Proteobacteria.

The new isolates are not related closely enough to the genus Desulfurella ( $87 \%$ sequence identity) to be considered members of that genus. On the basis of phenotypic and genomic differences, including very different $\mathrm{G}+\mathrm{C}$ contents of the DNA and a distinct phylogenetic position, we propose a new genus Hippea gen. nov., with type species Hippea maritima gen. nov., sp. nov.

\section{Description of Hippea gen. nov.}

Hippea (Hip'pea. L. fem. n. after Hans Hippe, a German microbiologist, in recognition of his significant contribution to the characterization of new, obligately anaerobic prokaryotes and the understanding of their physiology).

Cells are Gram-negative rods. Moderate thermophiles. Neutrophiles to moderate acidophiles. Obligate anaerobes. Metabolize by reduction of elemental sulfur. Capable of lithotrophic growth with $\mathrm{H}_{2}$ and sulfur. Oxidize completely volatile fatty acids, fatty acids and alcohols. Growth products are $\mathrm{CO}_{2}$ and $\mathrm{H}_{2} \mathrm{~S}$. The $\mathrm{G}+\mathrm{C}$ content of the DNA of the type strain of the type species is $40 \mathrm{~mol} \%$. Inhabit submarine hot vents. The type species is Hippea maritima.

\section{Description of Hippea maritima sp. nov.}

Hippea maritima (ma.ri'ti.ma. L. fem. adj. maritima inhabiting marine environments).

Cells are short, Gram-negative rods, single or in pairs, motile with one polar flagellum. Moderate thermophiles with growth temperature range of $40-65^{\circ} \mathrm{C}$ and optimal growth at $52-54{ }^{\circ} \mathrm{C}$. Neutrophiles to moderate acidophiles with $\mathrm{pH}$ growth range of 5.4-6.5 and optimal growth at pH 6.0. Obligate anaerobes. Require $2 \cdot 5-3 \%(\mathrm{w} / \mathrm{v}) \mathrm{NaCl}$ for growth. Metabolize by reduction of elemental sulfur. Growth substrates are $\mathrm{H}_{2} / \mathrm{CO}_{2}$, acetate, stearate and palmitate. Weak growth on fumarate. Some strains are able to utilize ethanol. No growth with formate, propionate, butyrate, pyruvate, lactate, succinate, glucose, starch, peptone, methanol or hexadecane. Elemental sulfur is required for growth and cannot be substituted for by thiosulfate, sulfate, sulfite, fumarate, cystine, nitrate or ferric iron. Growth products are $\mathrm{CO}_{2}$ and $\mathrm{H}_{2} \mathrm{~S}$. Yeast extract $(0.02 \% \mathrm{w} / \mathrm{v})$ is required for growth. The $\mathrm{G}+\mathrm{C}$ content of the DNA of the type strain is $40 \mathrm{~mol} \%$. Inhabits submarine hot vents rich in organic compounds and elemental sulfur. Isolated from hot vents in the tidal zone of Matupi Harbour, Papua New Guinea and shallow-water hot vents of the Bay of Plenty, New Zealand. The type strain of Hippea maritima is $\mathrm{MH}_{2}{ }^{\mathrm{T}}$ $\left(=\right.$ DSM $\left.10411^{\mathrm{T}}\right)$.

\section{ACKNOWLEDGEMENTS}

This work was supported by the International Science Foundation, grants N 64000 and N 64300. The work of M.M. was partly supported by DSMZ. The authors are grateful to Vitaly Tarasov, Institute of Marine Biology, Far East Scientific Center, Russian Academy of Sciences, for the organization of scientific cruise, to Nadezhda Kostrikina, Institute of Microbiology, Russian Academy of Sciences, who did electron micrographs of whole cells, to Jutta Burghardt and Silke Prudella, German Collection of Microorganisms and Cell Cultures, for their help with genomic analyses and to Dr Georgy Zavarzin for fruitful discussions.

\section{REFERENCES}

Balch, W. E., Fox, G. E., Magrum, L. J., Woese, C. R. \& Wolfe, R. S. (1979). Methanogens: reevaluation of a unique biological group. Microbiol Rev 43, 260-296.

Bonch-Osmolovskaya, E. A. (1994). Bacterial sulfur reduction in hot vents. FEMS Microbiol Rev 15, 65-67.

Bonch-Osmolovskaya, E. A., Sokolova, T. G., Kostrikina, N. A. \& Zavarzin, G. A. (1990). Desulfurella acetivorans gen. nov., sp. nov. - a new thermophilic sulfur-reducing eubacterium. Arch Microbiol 153, 151-155.

De Soete, G. (1983). A least squares algorithm for fitting additive trees to proximity data. Psychometrika 48, 621-626.

Jukes, T. H. \& Cantor, C. R. (1969). Evolution of protein molecules. In Mammalian Protein Metabolism, vol. 3, pp. 21-132. Edited by H. N. Munro. New York: Academic Press.

Maidak, B. L., Larsen, N., McCaughey, M. J., Overbeek, R., Olsen, G. J., Fogel, K., Blandy, J. \& Woese, C. R. (1994). The Ribosomal Database Project. Nucleic Acids Res 22, 3485-3487.

Miroshnichenko, M. L., Gongadze, G. A., Lysenko, A. M. \& BonchOsmolovskaya, E. A. (1994). Desulfurella multipotens $\mathrm{sp}$. nov., a new sulfur-respiring thermophilic eubacterium from Raoul Island (Kermadec archipelago, New Zealand). Arch Microbiol 161, 88-93.

Miroshnichenko, M. L., Rainey, F. A., Hippe, H., Chernyh, N. A., Kostrikina, N. A. \& Bonch-Osmolovskaya, E. A. (1998a). Desulfurella kamchatkensis sp. nov. and Desulfurella propionica sp. 
nov., new sulfur-respiring thermophilic bacteria from Kamchatka thermal environments. Int J Syst Bacteriol 48, 475-479.

Miroshnichenko, M. L., Kostrikina, N. A., Hippe, H., Slobodkin, A. I. \& Bonch-Osmolovskaya, E. A. (1998b). Biodiversity of thermophilic sulfur-reducing bacteria: new substrates and new habitats. Microbiology (English translation of Mikrobiologiya) 67, 563-568.

Rainey, F. A., Toalster, R. \& Stackebrandt, E. (1993). Desulfurella acetivorans, a thermophilic, acetate-oxidizing and sulfur-reducing organism, represents a distinct lineage within the Proteobacteria. Syst Appl Microbiol 16, 373-379.

Rainey, F. A., Ward-Rainey, N., Kroppenstedt, R. M. \& Stackebrandt, E. (1996). The genus Nocardiopsis represents a phylo- genetically coherent taxon and a distinct actinomycete lineage : proposal of Nocardiopsaceae fam. nov. Int J Syst Bacteriol 46, 1088-1092.

Trüper, H. G. \& Schlegel, H. G. (1964). Sulfur metabolism in Thiorhodaceae. I. Quantitative measurements on growing cells of Chromatium okenii. J Microbiol Serol 30, 225-232.

Widdel, F. \& Pfennig, N. (1992). The genus Desulfuromonas and other Gram-negative sulfur-reducing eubacteria. In The Prokaryotes, 2nd edn, vol. 1, pp. 3379-3389. Edited by A. Ballows, H. G. Trüper, M. Dworkin, W. Harder \& K. H. Schleifer. New York: Springer.

Wolin, E. A., Wolin, M. J. \& Wolfe, R. S. (1963). Formation of methane by bacterial extracts. J Biol Chem 238, 2882-2888. 